\title{
论 文
}

\section{基于转录组测序在人类全基因组内鉴定与癌症相 关的 polyadenylation 和 non-polyadenylation RNA}

\author{
赵国光 ${ }^{(1) \dagger}$ ，焦飞 ${ }^{(3 \dagger}$ ，廖奇 ${ }^{(4)}$, 罗海涛 ${ }^{(1)}$, 李慧 ${ }^{(1)}$, 孙亮 ${ }^{(1)}$ ， 卜德超 ${ }^{(1)}$, \\ 余鲲涛 ${ }^{1}$, 赵屹 ${ }^{1} *$, 陈润生 ${ }^{(1) *}$ \\ (1) 中国科学院计算技术研究所生物信息学研究组智能信息处理重点实验室, 北京 100190 ; \\ (2) 中国科学院大学, 北京 100190; \\ (3) 滨州医学院生物化学与分子生物学系, 烟台 264003; \\ (4) 宁波大学医学院预防医学系, 宁波 315211; \\ (5) 吉林大学计算机科学与技术学院, 长春 130012; \\ (6) 中国科学院生物物理研究所, 生物信息和生物大分子国家重点实验室, 北京 100101 \\ $\dagger$ 同等贡献 \\ * 联系人, Email: biozy@ict.ac.cn; crs@sun5.ibp.ac.cn
}

摘要 真核生物的 mRNA 包括 2 种形式的转录本, 根据它们 $3^{\prime}$ 端是否存在 poly(A)尾巴, 可以分为带 $\operatorname{poly}(\mathrm{A})$ 的 mRNA(简写成 poly(A)+mRNA)和不带 poly(A)的 mRNA(简写成 poly(A)-mRNA). Poly(A)+mRNA 的主要功能是促进蛋白质的编码, 但是对 poly(A)- mRNA 的功能却知之甚少. 而已有的研究表明, poly(A)-mRNA 和双态(bimorphic)的 mRNA(即包含 poly(A)+mRNA 又包含 poly(A)-mRNA) 也是基因转录的一个重要部分. 本研究通过建立一 个综合性的数据分析流程，首先从不同细胞系中鉴定出这些不同形式的 mRNA，然后比较 这些 poly(A)+及 poly(A)-mRNA 在正常细胞系和对应的癌症细胞系中的表达差异, 从而确 定这些 RNA 转录物的潜在功能. 通过生物信息学的分析表明, 在正常和肿瘤细胞系中确实 存在差异表达的 poly(A)+和 poly(A)-mRNA. 对差异表达的基因进行功能富集, 结果表明, 这 2 类 mRNA 都富集了包括细胞周期、细胞调亡及细胞死亡相关的功能，而这些功能已经 被证明和癌症的发生和发展是密不可分的. 此外, 还有一类差异表达的 poly(A)-mRNA 富 集了和翻译及翻译延长相关的功能. 因此, 本研究表明, poly(A)-mRNA 也可能在癌症的发 生和发展中发挥着重要的作用。

关键词

多聚腺苷酸化 非多聚腺苷酸化 功能注释 高通量测序 癌症生物信息学

引用格式: 赵国光, 焦飞, 廖奇, 等. 基于转录组测序在人类全基因组内鉴定与癌症相关的 polyadenylation 和 non-polyadenylation RNA. 中国科学: 生命科学, 2013, 43: 376-386

英文版见: Zhao G G, Jiao F, Liao Q, et al. Genome-wide identification of cancer-related polyadenylated and non-polyadenylated RNAs in human breast and lung cell lines. Sci China Life Sci, 2013, 56, doi: 10.1007/s11427-013-4485-1 
真核生物的 mRNA 可以根据它们是否存在 $3^{\prime}$ 端 的 poly(A)尾巴, 分成 2 种形式的转录本, 即带 poly(A) 的 mRNA(polyadenylation mRNA, 即多聚腺苷酸化 信使 RNA，简写成 poly(A)+mRNA)和不带 poly(A)的 mRNA(nonpolyadenylation mRNA, 即非多聚腺苷酸 化信使 RNA, 简写成 poly(A)-mRNA $)^{[1,2]}$; 而另外还 存在一些 mRNA, 它们可以同时包含 $\operatorname{poly}(\mathrm{A})+$ 和 poly(A)-两种形式的 mRNA, 被 Katinakis 等人 ${ }^{[3]}$ 称作 双态的 mRNA. Poly(A)+mRNA 3'端的 poly(A)尾巴 有利于 mRNA 的稳定、光滑核质出口及促进蛋白质 的翻译. 已知的大多数 mRNA 都是带 poly(A)尾巴 的 ${ }^{[4]}$, 而那些不带 poly(A)尾巴的 mRNA 通常包括核 糖体 $\mathrm{RNA}^{[5]}$ 、组蛋白的 $\mathrm{RNA}^{[6]}$ 、tRNA、某些小的非 编码 $\mathrm{RNA}^{[7]}$ 及一些长非编码 $\mathrm{RNA}^{[8]}$. 有研究认为, 所 有有功能的 mRNA 都是带 poly(A)尾巴的, 因此目前 的研究大多数关注的是已知注释的 poly (A) +mRNA, 相反, 对 poly(A)-mRNA 的研究却很少 ${ }^{[9,10]}$. 然而, 随着测序技术的进步, 人们通过测序对细胞转录进 行了越来越细致的研究, 因此, 越来越多的文献对不 带 poly(A)尾巴的 mRNA 也进行了报道 ${ }^{[1,11]}$. 下面举 例说明: Cheng 等人 ${ }^{[12]}$ 利用芯片数据分析发现人类的 8 个细胞系中有 10 个染色体上转录的基因中有 $43.7 \%$ 是不带 poly(A)尾巴的; $\mathrm{Wu}$ 等人 ${ }^{[1]}$ 使用 454 测序仪对 来自 HeLa 细胞系细胞质的 13467 条不同的 $3^{\prime} \mathrm{EST}$ 进 行测序, 结果发现 64\%的 EST 序列都是不带 poly(A) 尾巴的; Yang 等人 ${ }^{[11]}$ 使用 RNA-seq 测序方法分别对 人类胚胎干细胞系 $\mathrm{H} 9$ 和 HeLa 细胞系进行转录组的 测序, 然后分别对这 2 个细胞系中转录的 mRNA 进行 poly(A)-的鉴定, 发现分别有 1911 条(占 15.8\%)和 2828 条(占 25.8\%) mRNA 为 poly(A)-mRNA 或者双态 的 mRNA. 总之, poly(A)-mRNA 或者双态 mRNA 是 人类细胞系转录产物中非常重要的组成部分. 虽然 如此, 但是对它们功能的研究却比较少, 尤其是对那 些在正常细胞系和癌症细胞系中差异表达的 mRNA 功能知之甚少. 最近的一篇文献发现锌指因子蛋白 家族的一员 ZNF 具有不带 poly(A)尾巴的非组蛋白 mRNA, znf460 和 sesn $3^{[11]}$. 因此, 为了能够更好地了 解这些不带 poly(A)的 mRNA 在癌症的发生发展中所 起的作用, 很有必要对这些在正常细胞系和癌症细 胞系中差异表达的 poly(A)-或者双态 mRNA 进行功 能的研究.

在本研究中, 分别从 HMEC, MCF-7, NHLF 和
A549 细胞系转录产物中鉴定 $\operatorname{poly}(\mathrm{A})+$ 及 $\operatorname{poly}(\mathrm{A})-$ mRNA, 并发掘它们在人类癌症的潜在功能. 为此, 首先对这 4 个细胞系的 8 个 RNA-seq 测序样本进行 转录组分析 (因为每个细胞系包含带 poly (A)及不带 poly(A)尾巴的 mRNA, 所以每个细胞系有 2 种 RNAseq 测序 $)^{[13]}$.

\section{1 材料与方法}

\section{1 数据集}

本研究共使用了 8 个链特异性的 RNA-seq 测序数 据集，如网络版附表 1 所示. 总共来自 4 个细胞系: 正 常人类乳腺上皮细胞系(human mammary epithelial cell line HMEC)、人类乳腺癌细胞系(breast cancer cell line MCF-7)、人类正常肺纤维母细胞(human lung fibroblast cell line NHLF)及人类肺癌细胞系(lung cancer cell line A549). 每个细胞系包含带 poly(A)及不带 poly(A)尾巴 的 mRNA 两种 RNA-seq 测序. 这 8 个 RNA-seq 测序数 据集是 ENCODE(the Encyclopedia of DNA Elements)计 划的一部分, 由美国冷泉港实验室使用 Illumina GA II $\mathrm{x}$ 测试平台测序得到, 测序流程可以通过美国国立 生物技术信息中心的网站(http://www.ncbi.nlm. nih.gov/pubmed/19620212)来查看 ${ }^{[13]}$. 这 8 个 RNAseq 测序数据共包含 808.7 百万读段(read)的双末端 (paired end)测序数据, 每端的长度为 $76 \mathrm{bp}$. 所有这 些数据访问编号为 GSE30567, 可以通过美国国立 生物技术信息中心基因表达综合网站(NCBI Gene Expression Omnibus)(http://www.ncbi.nlm.nih.gov/ geo)下载.

本研究使用的人类参考基因组是 $\mathrm{Hg} 19$, 注释资 源包括 Refseq 数据库、UCSC 注释数据集、GENCODE 数据集、Ensembl 数据集, 所有这些数据可以通过美国 加利福尼亚大学基因组的网站(http://genome.ucsc.edu/ cgi-bin/hgTables?command=start)下载, 具体描述见网 络版附表 2.

\section{2 鉴定不同可变加尾的 mRNA：poly(A)+, poly(A)-及双态}

首先，需要使用生物信息学的方法鉴定出不同 细胞系中不同可变加尾的 mRNA 的分布情况, 下面 具体描述不同可变加尾的 mRNA 的鉴定过程(图 1).

(1) 转录本的整合. 这个模块主要目的是得到 


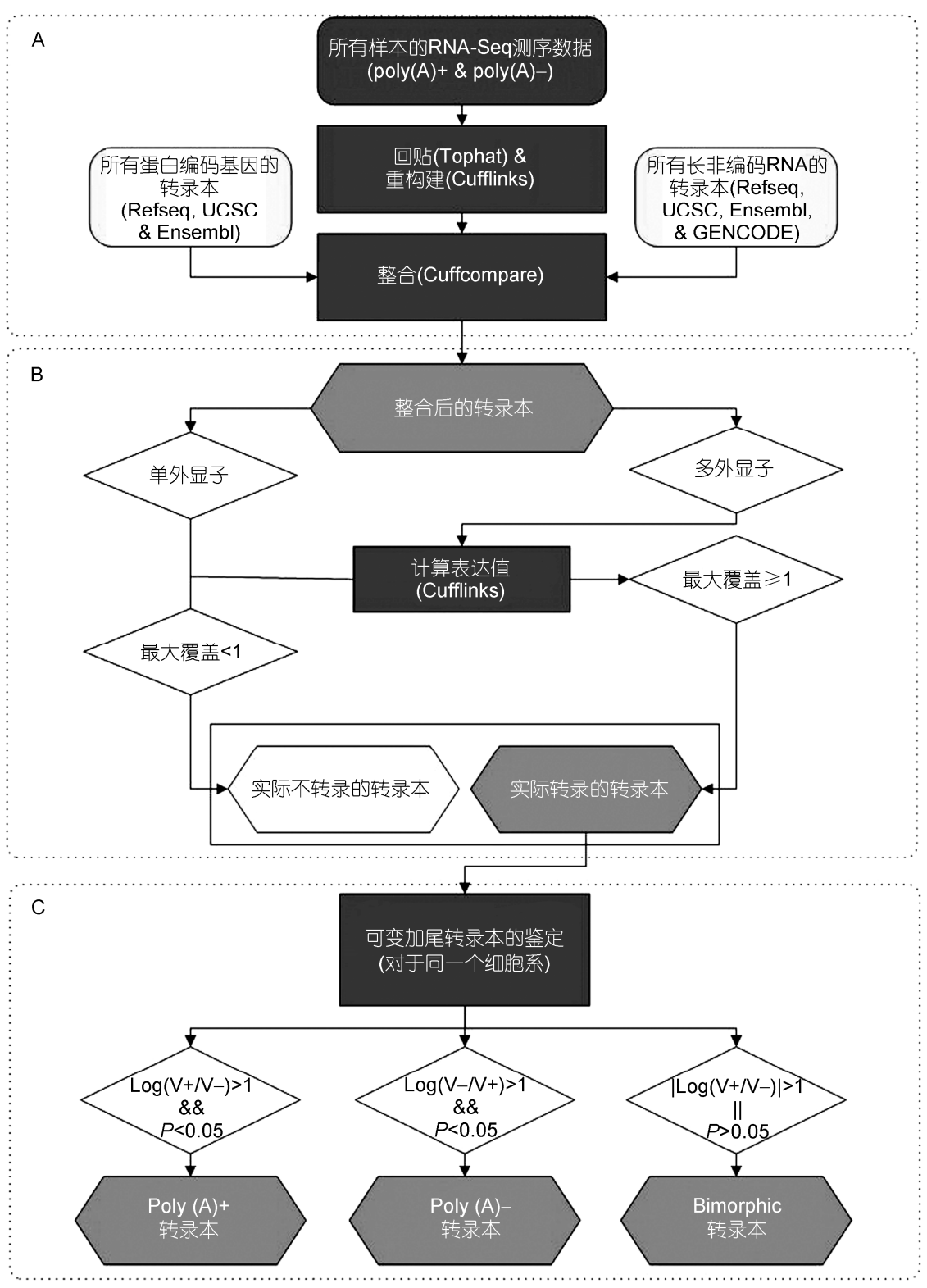

图 1 鉴定不同可变加尾的基因转录本的分析流程

A：使用生物信息学方法整合转录本, 使用 Cuffcompare 整合从新构建的转录本, Refseq, UCSC, GENCODE 及 Ensembl 数据库成为“整合后的 转录本”, 包括编码基因和非编码基因; B: 从“整合后的转录本”中滤出表达的转录本, 覆盖度低于 1 和单个外显子的转录本被滤除, 滤除的 转录本被标定为“实际不转录的转录本”, 滤出的转录本被标记为“实际转录的转录本”; $\mathrm{C}$ : 分出不同可变加尾的转录本; V+: 某转录本在细胞 系 poly(A)+测序样本中的表达值; V-: 该转录本在同一个细胞系的 poly(A)-测序样本中的表达值

一个整合后完整的转录本集合, 这个集合的数据来源 主要包括 2 个部分, 一部分是从 RNA-seq 测序样本中 从新构建的转录本, 第二部分是已知数据库注释的转 录本(图 1A).

为了得到新构建的转录本, 需要经过 2 个过程: 第一个过程是回贴, 把通过 RNA-seq 测序所得到的
短序列或者读段回贴到基因组; 第二个过程是重新 构建, 通过拼接第一步回贴到基因组的短序列来重 新构建转录本.

( i ) RNA-seq 短序列的回贴. 流程中使用一个 能够快速寻找可变剪接的回贴工具 TopHat(版本 V1.4.1 ${ }^{[14]}$ 来把 RNA-seq 测序所得的短序列回贴到人 
类基因组(版本 $\mathrm{Hg} 19$ ). 该工具基于短序列回贴工具 Bowtie $^{[15]}$, 它可以快速确认 exon-exon 剪切事件. 简 单来讲, TopHat 分 2 步来完成回贴: 第一步, 使用短 序列比对工具 Bowtie 来把 RNA-seq 测序所得的短序 列回贴参考基因组, 这次回贴过程把每个测序所得 的短序列作为整体来回贴到基因组, 即短序列必须 完全匹配到基因组, 不允许短序列中出现空缺(gap) 的回贴; 第二步, 对于第一步中没有回贴到基因组的 短序列, 依据一定的规则把这些短序列打断, 基于已 有的剪接位点信息来进行匹配, 即允许有空缺的回 贴 ${ }^{[14]}$. 这样导致更多的短序列回贴到了基因组, 同时 也更真实地反映了实际转录的情况. 为了充分利用 剪接位点信息, 让更多的短序列回贴到基因组, 更真 实地反应实际转录本的情况, 在使用 TopHat 做回贴 时, 做了 2 次迭代式的回贴. 第一次迭代, 首先产生剪 接位点库, 它们来自 15 个细胞系, 63 个样本回贴时产 生的剪接位点(测序数据来自冷泉港实验室, 测序源于 ENCODE 计划, 测序数据访问编号 GSE30567) ${ }^{[13]}$. 接 着, 使用第一次迭代产生的剪接位点库作为输入, 接 着进行第二次迭代, 参数使用“raw-juncs”和“no-noveljuncs”. 经过这 2 次的 TopHat 迭代, 能够充分利用剪 接位点(splice sites)或者说 junction 的信息, 提高短序 列的回贴率.

(ii) RNA-seq 转录组的重新构建. 为了寻找新 的转录本或者基因, 需要基于 TopHat 回贴基因组后 的信息进行转录本的重新构建, 这里重新构建使用 的是 Cufflinks ${ }^{[16]}$. 简单来说, Cufflinks 是一款根据回 贴基因组后的短序列信息进行转录组拼接的工具, 它基于统计模型, 为用户提供一个具有最大似然的 转录本集合, 相比其他构建工具, 它构建出的转录本 较假阳性较低 ${ }^{[17]}$. 与 Cufflinks 同系列的工具还包括 Cuffcompare 及 Cuffdiff, Cuffcompare 用于整合来自 不同数据库的转录本并进行攵余去除, Cuffdiff 用于 对基因进行差异表达分析.

(iii) 转录本的整合. 为了得到无呪余的转录本 集合, 使用 Cuffcompare ${ }^{[16]}$ 来整合新构建出的转录本 和已知注释的转录本, 其中已知注释的转录本包括来 自 Refseq, UCSC, Ensembl 及 GENCODE 11 注释的转 录本集合. 构建这个无午余的转录本集合的好处: (1) 能够弥补一些在构建过程中没有被构建出来的缺 失的转录本; (2) 由于 Cufflinks 中使用了随机采样算
法, 在使用 Cufflinks 进行转录本表达值求解时, 不同 大小的转录本集合在求解时, 所得到的表达值会有偏 差, 因此最好整合出一个无冗余的转录本集合进行一 次表达值求解, 使得后续的基于表达值的分析更加准 确并且更具有说服力; (3) 合并后, 所有的转录本具有 了统一的编号, 便于后续的分析和计算.

(2) 过滤噪音转录本. 计算出转录本的表达值, 并过滤掉噪音转录本(图 1B).

(i) 计算转录本的表达值. 使用 Cufflinks ${ }^{[16]}$ 一 次性计算出给定无午余集合中转录本在不同样本中 的表达值.

(ii) 过滤掉低表达噪音转录本. 正如 Cabili 等 人 $^{[18]}$ 的研究结果, 在转录本分析过程中一个挑战即 是如何区分表达出的转录本和不表达的背景噪音转 录本. 本次研究使用测序后的短序列拼接后对转录 本的覆盖次数 (coverage) 1 作为过滤的阈值来滤除那 些小于 1 的转录本, 而大于 1 的转录本标注为 “实际 表达的转录本”(图 1B).

(3) 鉴定不同可变加尾的转录本 poly(A)+, $\operatorname{poly}(\mathrm{A})$ - 及双态. 根据转录本在给定细胞系的 $\operatorname{poly}(\mathrm{A})+$ 及 $\operatorname{poly}(\mathrm{A})-$-测序样本中的差异表达情况来确 定转录本的不同可变加尾(图 1C). 这里使用差异表达 分析的软件 Cuffdiff ${ }^{[16]}$ 来计算过滤噪音后的转录本在 同一细胞系 $\operatorname{poly}(\mathrm{A})+$ 及 $\operatorname{poly}(\mathrm{A})-$ 测序样本中的差异 表达情况来确定该细胞系下不同可变加尾的转录本 $\operatorname{poly}(\mathrm{A})+, \operatorname{poly}(\mathrm{A})-$ 及双态. 以 $\operatorname{poly}(\mathrm{A})+$ 为主导的转录 本, 简称 $\operatorname{poly}(\mathrm{A})+$ 转录本, 定义为在 $\operatorname{poly}(\mathrm{A})+$ 的 RNA-seq 测序样本及 poly(A)-的 RNA-seq 测序样本 中显著差异, 在前者中的表达值要高于在后者中的 表达值 2 倍(含 2 倍)以上, 且差异表达的 $P$ 值要小于 0.05 . 以 $\operatorname{poly}(\mathrm{A})-$ 为主导的转录本, 简称 $\operatorname{poly}(\mathrm{A})-$ 转 录本, 定义为在 poly(A)-的 RNA-seq 测序样本及 poly(A)+的 RNA-seq 测序样本中显著差异, 在前者中 的表达值要高于在后者中的表达值 2 倍(含 2 倍)以上, 且差异表达的 $P$ 值要小于 0.05 ; 双态的转录本, 指在 $\operatorname{poly}(\mathrm{A})+$ 及 $\operatorname{poly}(\mathrm{A})-$ 两个样本库中差异不显著, 或者 差异不满足 2 倍以上差距的转录本.

\section{2 结果}

\section{1 转录本构建的总体情况}

RNA-seq 测序数据包含了 808.7 百万短序列, 其 
中大约有 $80 \%$ 能够回贴到人类基因组中. 本研究使 用转录本重新构建的软件 Cufflinks, 从所有的 8 个 RNA-seq 测序样本中重新构建了 929754 条转录本, 其中 762941 条(占 $82.1 \%$ )来自 poly(A)-的 RNA-seq 测 序样本, 166813 条(占 $17.9 \%$ )来自 poly(A)+的 RNA-seq 测序样本. 在从 poly(A)-的 RNA-seq 测序样本中构 建出的转录本, 其中 597441 条(占 78.3\%)来自癌症的 细胞系(即 MCF-7 和 A549). 如表 1 所示, 总体来说, 大部分 $(64.2 \%)$ 的转录本是从 poly(A)-的癌症细胞系 的 RNA-seq 测序样本中构建出来的. 按照转录本所 含外显子的个数把转录本分成 2 类: 单外显子的转 录本和多外显子的转录本 (2 个及 2 个以上外显子). 对于多外显子的转录本, 其中有 96072 条(占 51.9\%) 来自 poly(A)+的 RNA-seq 测序样本, 89192 条(占 48.1\%)来自 poly(A)-的 RNA-seq 测序样本. 因此, poly(A)+的 RNA-seq 测序样本中含多外显子的比例 (60.6\%)要高于 poly(A)-的 RNA-seq 测序样本(16\%), 尤其从 poly(A)+正常细胞系样本中构建出的转录本 包含多外显子的比例更高, 能达到 $73 \%$, 而从 poly(A)-癌症细胞系样本构建出的转录本其含外显 子的比例却只有 $9.2 \%$. 从 poly(A)-测序样本中构建 出的单外显子的转录本的比例达到 $84.1 \%$, 其中从癌 症细胞系构建出的单外显子的比例更高, 达 $90.8 \%$. 相比之下, 从 poly(A)+样本中构建出的单外显子的转 录本只有 39.4\%. 此外, 从 poly(A)+测序样本中构建 出的转录本, 其平均长度要长于从 $\operatorname{poly}(\mathrm{A})$-测序样 本中构建出的转录本, 它们的长度分布见网络版附 图 1.

随后, 使用 Cuffcompare 工具 ${ }^{[16]}$, 把从所有样本 中构建出的多外显子的转录本和已知注释的 Refseq
库注释的转录本进行比对分析, 发现平均有 $66.6 \%$ 的多外显子的转录本和 Refseq 数据库中注释的编码 基因的转录本在外显子水平上有重合. 剩下的 $33.4 \%$ 的多外显子的转录本或者比对到已知的非编 码基因的转录本, 或者是新的非编码基因的转录本. 因此, 这些测序数据能够很好地表征细胞系中基因 的转录情况.

\section{2 不同细胞系中 $\operatorname{poly}(\mathrm{A})+, \operatorname{poly}(\mathrm{A})-$ 及双态的转 录本的分布情况}

随后, 设计出一套流程来把转录本分成不同的 可变加尾(图 2). 一条转录本按照其在 $\operatorname{poly}(\mathrm{A})+$ 的 RNA-seq 测序样本和 poly(A)-的 RNA-seq 测序样本 中的表达值差异, 分为 $\operatorname{poly}(\mathrm{A})+, \operatorname{poly}(\mathrm{A})-$ 或者双态 (详见材料与方法部分). 首先, 对重构建的转录本、 来自 Refseq 库注释的、UCSC 库注释的、Ensembl 库 注释的及 GENCODE 11 库中注释的转录本进行整合, 去除重复的转录本, 然后把这些整合后的转录本按 照不同的可变加尾分成不同的形式, 其中有 $44.7 \%$ 来 自双态的转录本， $37.5 \%$ 来自 poly $(\mathrm{A})+$ 的转录本, $17.8 \%$ 来自 $\operatorname{poly}(\mathrm{A})$ 的转录本 (网络版附图 2). 以来自 Refseq 的编码基因的转录本库为例, 如图 2 所示, 不同细胞系中所含的不同类别的转录本的比例有所 不同(基因列表见网络版附加文件 2). 通过过滤, 共 从 4 个乳腺细胞系相关的测序样本中过滤出 15841 条表达的转录本, 从 4 个肺细胞系相关的测序样本 中过滤出 16777 条表达的转录本. 计算表明, 所有 的细胞系中 poly(A)+转录本的平均比例是 $52.3 \%$, 而大约有 $10 \%$ 的转录本来自 poly(A)-样本, 其余的 是双态转录本(图 2).

表 18 个样本中转录本的重构及与 Refseq 注释的基因数据集进行比较

\begin{tabular}{lccccc}
\hline 样本名称 & 构建的转录本 & 多外显子的转录本 & $\begin{array}{c}\text { 多外显子转录本 } \\
\text { 比率 }(\%)\end{array}$ & $\begin{array}{c}\text { 多外显子的转录本和 } \\
\text { Refseq 数据库注释的 } \\
\text { 转录本重合情况 }\end{array}$ & $\begin{array}{c}\text { 奋fseq 数据库注释的 } \\
\text { 转录本重合的 } \\
\text { 百分比 }(\%)\end{array}$ \\
\hline HMEC-poly(A)+ & 29326 & 22274 & 76 & 16078 & 72.1 \\
HMEC-poly(A)- & 82360 & 16727 & 20.3 & 10885 & 65.1 \\
MCF-7-poly(A)+ & 55854 & 24971 & 44.7 & 16716 & 66.9 \\
MCF-7-poly(A)- & 379206 & 26829 & 7.1 & 16276 & 60.1 \\
NHLF-poly(A)+ & 35416 & 24455 & 69.1 & 17807 & 72.8 \\
NHLF-poly(A)- & 83140 & 20886 & 25.1 & 12960 & 62.1 \\
A549-poly(A)+ & 46217 & 24372 & 52.7 & 16713 & 68.6 \\
A549-poly(A)- & 218235 & 24750 & 11.3 & 16146 & 65.2 \\
\hline
\end{tabular}




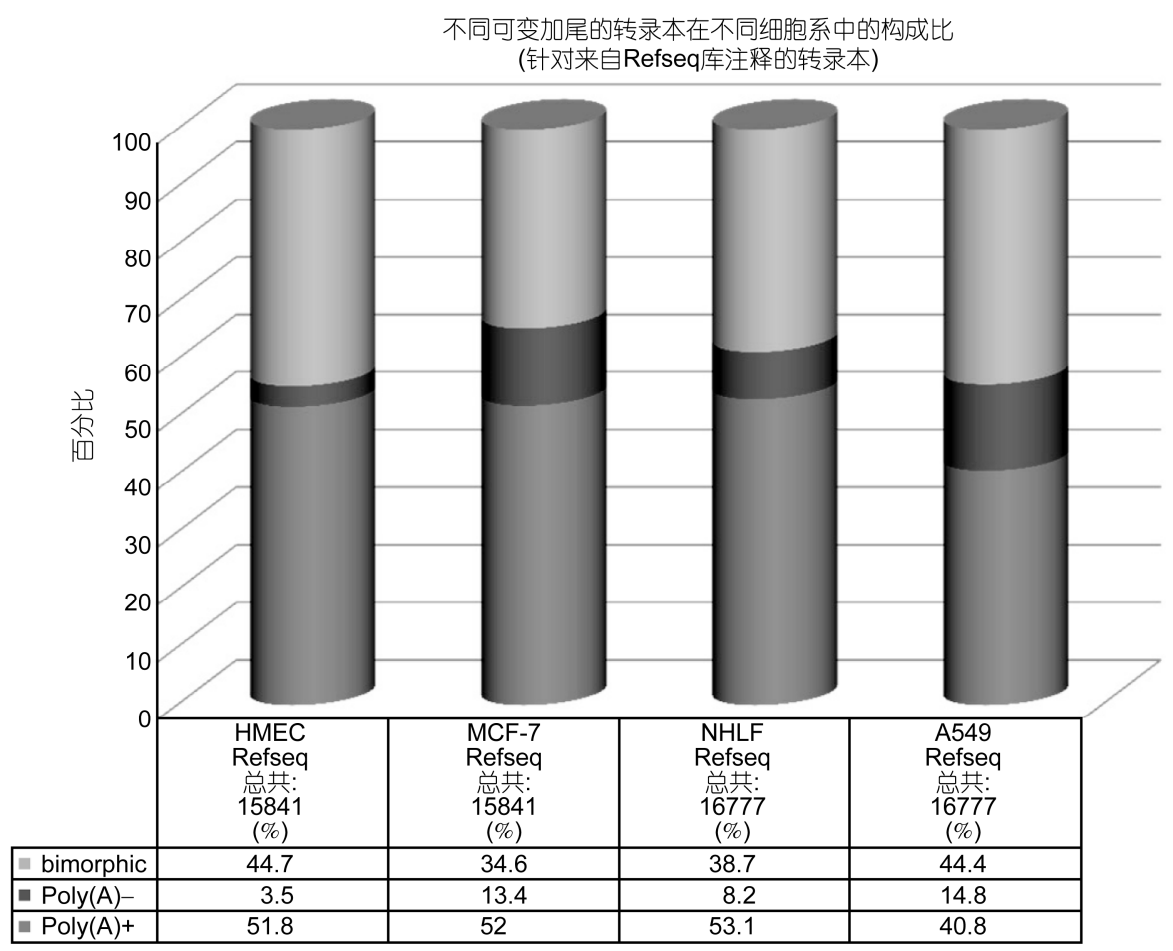

图 $2 \operatorname{poly}(\mathrm{A})+, \operatorname{poly}(\mathrm{A})$-及双态编码基因转录本在不同细胞系中的分布(来自 Refseq 数据库注释)

每个转录本在 HMEC, MCF-7, NHLF 和 A549 这 4 个细胞系中的表达水平采用 FPKM 值来度量, 依据转录本在 poly(A)+及 poly(A)-样本中 的表达差异来确定转录本所属态的类别

为了进一步得到不同可变加尾的转录本的一些 基本特征, 把不同可变加尾的转录本进行了序列特征 和表达特征的比较(图 2). 结果表明, 这 3 种形式的转 录本的平均外显子个数相同, 但是长度都有所差别: poly(A)+平均 $3.8 \mathrm{~kb}$, poly(A)-的平均 $4.7 \mathrm{~kb}$, 双态平均 $4.2 \mathrm{~kb}$. 对于表达值而言, 发现 poly(A)+的编码基因的 转录本的表达值从总体上要大于其他 2 种形态的转录 本的表达值(图 3).

\subsection{4 种细胞系中 poly(A)+, poly(A)-及双态的基} 因在正常和癌症细胞系中差异表达的情况

为了获得癌症和正常细胞系中差异表达的转录 本, 首先得到在癌症和正常细胞系中都表达的基因 的转录本, 然后对这 2 个集合求交集(网络版附图 3 和附加文件 3). 然后使用 Cuffdiff ${ }^{[16]}$ 对这些交集的基 因进行差异表达分析(差异表达基因列表见网络版附 加文件 1). 使用 $P$ 值小于 0.05 和差异表达 2 倍作为 过滤的阈值, 发现在肺的癌症细胞系比肺的正常细 胞系上调的 poly(A)+态的基因有 1043 条, 下调的有 1172 条; 使用同样的阈值, 在乳腺癌细胞系对正常
的乳腺细胞系，上调的 $\operatorname{poly}(\mathrm{A})+$ 态的基因有 1422 条， 下调的有 1188 条(表 2). 相比 poly(A)+态的基因, 在 癌症细胞系和正常细胞系中差异表达的 poly(A)-态 基因显得比较少，使用和上述过滤相同的阈值，肺的 癌症细胞系相比肺的正常细胞系上调的 poly(A)-态 的基因有 45 条, 下调的有 192 条; 乳腺癌细胞系相对 正常的乳腺细胞系，上调的 poly(A)+态的基因有 24 条, 下调的有 37 条(表 2).

\section{4 在正常和癌症中差异表达的 $\operatorname{poly}(A)+, \operatorname{poly}(A)-$ 及双态基因的潜在功能}

下一步，使用生物信息学工具 David 进行 Gene Ontology $(\mathrm{GO})$ 功能注释来对差异表达的基因进行功能 富集和预测. 分析发现, 相比正常的细胞系, 在肺癌细 胞系中上调的 poly(A)-的编码基因主要富集以下功能: 基因翻译延伸(gene translation elongation)、蛋白质氨 基酸去磷酸化(protein amino acid dephosphorylation)、 翻译(translation)、酶联受体蛋白质信号转导通路(the enzyme-linked receptor protein signaling pathway)、跨 膜受体蛋白丝氨酸/苏氨酸激酶信号传导通路(the 

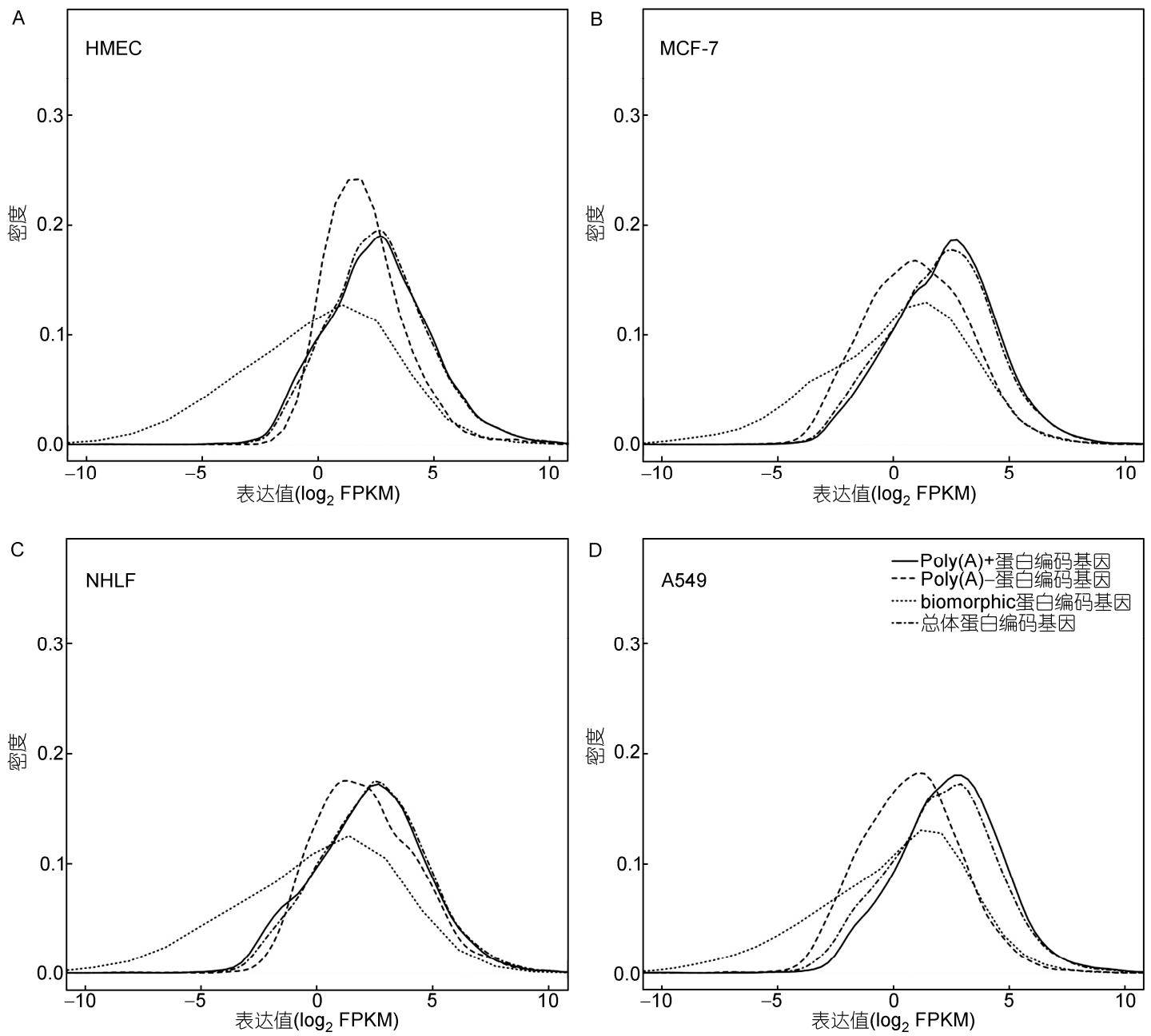

图 3 不同细胞系中 $\operatorname{poly}(\mathbf{A})+, \operatorname{poly}(\mathrm{A})$-及双态编码基因转录本的表达特征

不同可变加尾的编码基因转录本在 HMEC, MCF-7, NHLF 和 A549 4 个细胞系中的表达值分布的比较(表达值采用 $\log _{2}$ 正则)

表 2 正常与癌症细胞系中差异表达的 poly(A)+, poly(A)基因转录本的总体情况 ${ }^{\text {a) }}$

\begin{tabular}{lrr}
\hline & 肺 & 乳腺 \\
\hline poly(A)+ $(\uparrow)$ & 1043 & 1422 \\
poly(A)+ $(\downarrow)$ & 1172 & 1188 \\
poly(A)- $(\uparrow)$ & 45 & 24 \\
poly(A) $-(\downarrow)$ & 192 & 37 \\
\hline
\end{tabular}

a) $\uparrow$ : 癌症/正常表达上调; $\downarrow$ : 癌症/正常表达下调; 上下调 的基因的转录本具体信息参看网络版附加文件 1

transmembrane receptor protein serine/threonine kinase signaling pathway)和 BMP(骨形态发生蛋白-bone morphogenetic protein)信号通路(signaling pathway) (图 4). 对于乳腺癌细胞系相比乳腺正常细胞系中上 调的 poly(A)-的编码基因, 也同样富集诸如基因翻译
延伸和翻译等功能. 而对于癌症细胞系相比正常细 胞系下调的基因, 它们的富集的功能主要和细胞死 亡及细胞周期相关(网络版附图 4).

那些 poly $(\mathrm{A})+$ 的编码基因主要富集的功能包括细 胞周期、调亡及细胞死亡(网络版附图 5 和 6). 有关的 文章早已报道所有这些基因在癌症中高表达 ${ }^{[19]}$.

此外, 本研究还发现同一个基因在正常细胞系 和癌症细胞系中会表现出不同的可变加尾. 例如, 在 癌症发生过程中一个在正常细胞中为 $\operatorname{poly}(\mathrm{A})+$ 态的 基因有可能会转变成 poly(A)-态的基因. 通过比较发 现, 在肺的细胞系和乳腺的细胞系中分别发现 460 和 476 个这种转换(基因列表见网络版附加文件 4). 同 样, 还有一些在正常细胞中是 $\operatorname{poly}(\mathrm{A})$-态的基因在癌 
症中转变成 $\operatorname{poly}(\mathrm{A})+$ 态的基因. 通过比较发现, 在肺 的细胞系和乳腺的细胞系中分别发现 153 和 223 个这 种转换(基因列表见网络版附加文件 4). 进而, 本实 验室对这些转换的基因进行功能分析, 结果显示, 在 正常细胞系中 $\operatorname{poly}(\mathrm{A})+$ 态的基因转变成癌症细胞系
中, $\operatorname{poly}(\mathrm{A})$-态的基因主要富集的功能包括细胞周期 编程和细胞调亡相关的功能(图 5); 而在正常细胞系 中 poly(A)-态的基因转变成癌症细胞系中 poly(A)+ 态的基因主要富集的功能包括负调控和 RNA 定位等 (网络版附图 7).

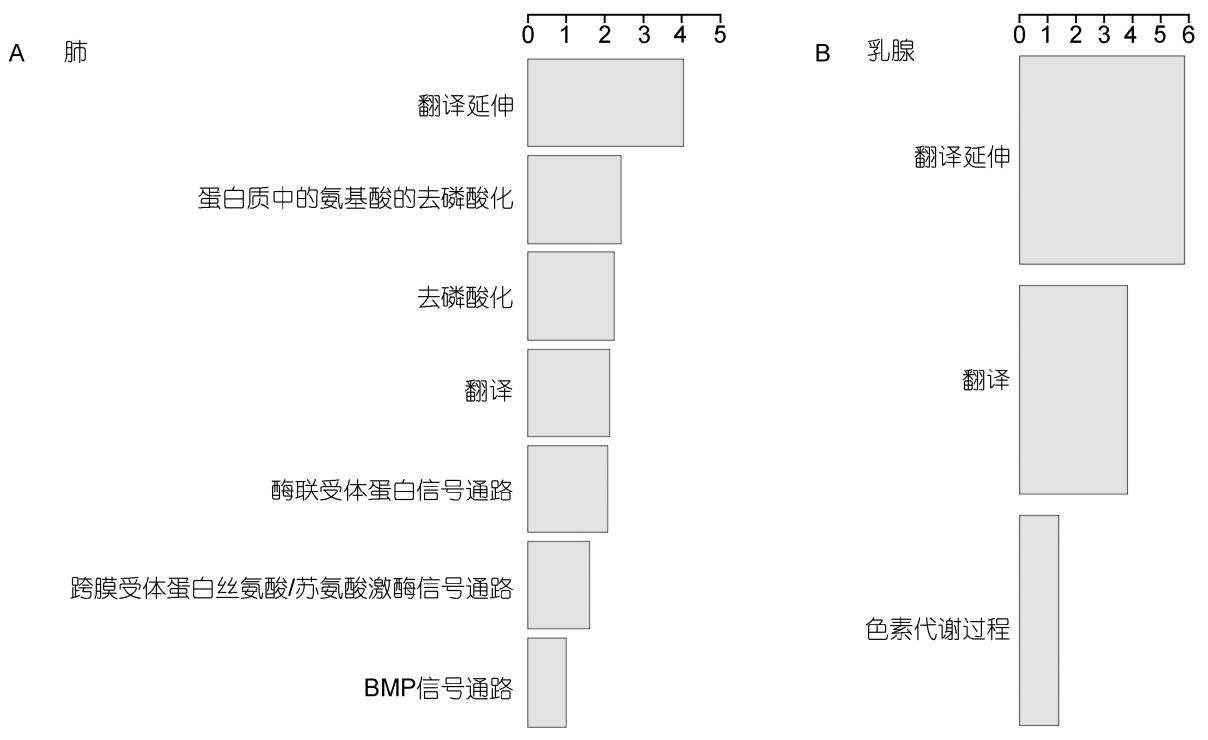

图 4 癌症/正常表达上调的 poly(A)- mRNA 的 GO 功能富集 A: A549/NHLF; B: MCF-7/HMEC

A 肺

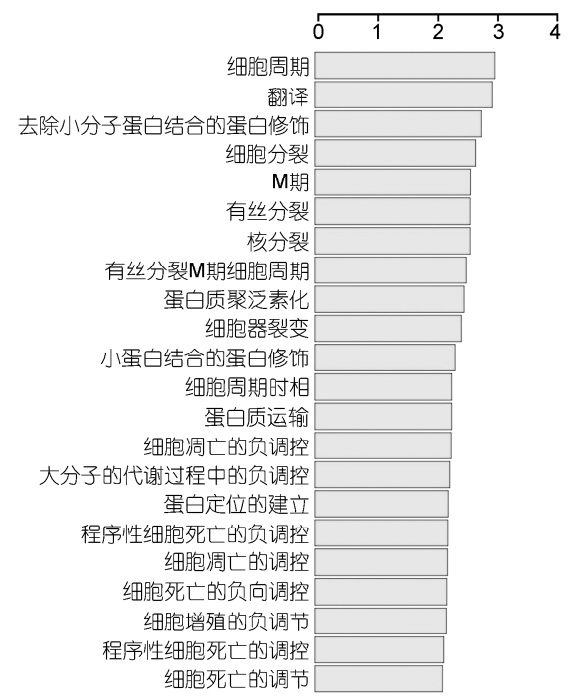

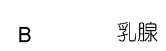

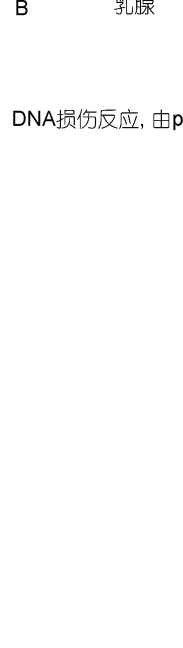

0.00 .51 .01 .52 .02 .53 .03 .5

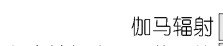

程序性细胞死亡的调控 细胞死亡的调节 凋亡的信号转导 电子传递链 细胞调亡的调控
细胞调亡 程序性细胞死亡

诱导细胞调亡 诱导程序性细胞死亡 细胞死亡 胞内运输 细胞成分大小调节 正向调控细胞调亡 细胞程序性死亡正调控 细胞死亡正调控 对紫外线的反应 逆行泡介导的运输, 高尔基到内质网 对辐射的反应 线粒体运输

图 5 在正常细胞系中表现为 poly(A)+, 在癌症细胞系中表现为 poly(A)-转换的 mRNA 的 GO 功能富集 A: A549/NHLF; B: MCF-7/HMEC; poly(A)-和 poly(A)+转换的 mRNA 是指同一个 mRNA, 在正常细胞系中被鉴定为 poly(A)- mRNA, 而在其对应的癌症细胞系中被鉴定为 poly $(A)+$ mRNA, 或者反之 


\section{3 讨论}

在本研究中, 开发了一套流程从 4 个细胞系 8 个 样本的 RNA-seq 测序数据中重构出转录本, 结果如下: ( i ) 一些已经注释的编码基因表现为 poly(A)-的形态; (ii ) 根据基因的转录本在 poly(A)+和 poly(A)-测序样 本中的表达差异, 转录本被分为 3 种形态: poly(A)+, poly(A)-及双态; (iii) 平均所有表达的基因转录本中 有一半是 $\operatorname{poly}(\mathrm{A})+$, 另外一半是 $\operatorname{poly}(\mathrm{A})-(10 \%)$ 或者 双态(40\%); (iv) GO 富集分析发现，一些差异表达的 poly(A)+和 $\operatorname{poly}(\mathrm{A})-$ 的基因富集的功能和细胞周期、 DNA 损坏及细胞调亡相关, 还有一些差异表达的 poly(A)-基因富集的功能与基因的翻译延长及翻译 相关, 这些表明一些 poly(A)+和 poly(A)-的基因在癌 症的发展过程中发挥着重要的作用. 因此, 本研究为 进一步研究 poly(A)-基因在癌症的发生发展过程中 所起的作用提供了证据.

调研发现, 首次使用 RNA-seq 数据从 2 种组织肺 和乳腺组织的 4 种细胞系 HMEC, MCF-7, NHLF 及 A549 这 8 个测序样本(每个细胞系包含带 polyA 和不 带 polyA 两种测序样本)中鉴定转录本, 然后对在正 常和癌症中差异表达的不同可变加尾的基因转录本 的功能进行研究. 结果发现, 在肺癌中高表达的 poly(A)+基因和 DNA 损伤及细胞周期相关, 而相关 文献中已有报道这些基因在癌症和许多其他疾病中 上调 ${ }^{[20,21]}$. 导致基因上调从而引起 DNA 损伤的刺激 因素来自紫外线或电离辐射和各种化学品等环境, 或来自细胞内部 ${ }^{[22]}$. 此外, 在癌症的发生和发展中细 胞周期的调控也会发生改变 ${ }^{[23,24]}$. 然而, 对于 poly(A)-的差异表达的基因, 这些基因的功能与蛋白 质翻译延伸相关. 例如, 核糖体蛋白 SA(RPSA)导致 蛋白质翻译延伸, 它在肺癌中上调, 结果和之前的研 究相吻合 ${ }^{[25,26]}$. EIF4EBP1 被称为翻译抑制因子, 具 有短的 poly(A)尾巴，据报道，其在肺癌患者体内过 度表达 ${ }^{[27,28]}$. EIF4EBP1 直接与真核翻译起始因子 $4 \mathrm{E}$ (EIF4E)相互作用，抑制蛋白质翻译复合体的装配并 抑制翻译. EIF4EBP1 的激活通过如紫外照射和胰岛 素信号等因素, 这些因素导致其从 eIF4E 中离解及相 应 mRNA 翻译的激活 ${ }^{[29]}$. EIF4EBP1 对于 AKT 和 ERK 信号通路致癌激活也是一个重要的效应因子, 在许 多癌症中也集成了这些功能 ${ }^{[30]}$.

此外, 在网络版附图 3 中展示了在癌症中下调的
基因富集的功能. 这些基因都与细胞死亡和细胞周 期调控相关，也同时都与肿瘤发生和进展有关 ${ }^{[19,31]}$. 还有一些在 poly(A)+和 poly(A)-间相互转化的基因, 它们富集的主要功能包括细胞周期、细胞死亡和调亡 这些基因的这种频繁的变化，经常会发生在肿瘤的 发生发展过程中 ${ }^{[19,32]}$. 由于 poly(A)可以影响 mRNA 稳定性和翻译的效率, 因此 poly(A)+和 poly(A)-之 间的转换或许可以改变转录本的表达, 进而在癌症 的发生发展过程中发挥作用; 由于受影响的转录本 参与细胞周期的调控, 进而细胞的增殖受到影响也 是合理的; 最终, 因为不适当的细胞增殖导致肿瘤 的发生 ${ }^{[33]}$. 同样的, 不适当的细胞调亡也会导致肿 瘤生成，因为调亡本身可以作为阻碍肿瘤发生的天 然屏障 ${ }^{[19]}$. 总的来说, poly(A)-基因或一个具有可变 的 poly(A)尾巴的基因可能都会影响肿瘤的发生和发 展. 所有这些结果表明, poly(A)-基因在癌症中发挥 了重要的作用.

此外, 越来越多的非编码 RNA 已经被鉴定出来, 并已发现在人类癌症中发挥着重要作用 ${ }^{[34 \sim 36]}$. 在目前 的研究中, 发现某些非编码 RNA 能调节基因的表达. 这些非编码 RNA，也同样包括 3 种形式, poly(A)+, poly(A)-及双态, 在癌症发展中可能发挥重要的作用. 事实上, 先前的研究已经表明, 在人类白血病中, p15AS(反义长非编码 RNA)能够沉默肿瘤抑制基因 P15 的表达 ${ }^{[37]}$; lincRNA-P21 在 p53 所属的转录反应 中起到抑制因子的作用 ${ }^{[38]}$; HOX 来自基因间区域的 反义 RNA(HOTAIR), 在调节癌症表观基因组和介导 细胞转化中发挥了积极的作用 ${ }^{[39]}$. 此外, PCAT-1 转 录抑制因子, 发现在前列腺癌病人体内起到非常重 要的作用 ${ }^{[40]}$. 因此, 不同形式的非编码 RNA 参与并 影响肿瘤发生和发展. 使用编码基因和非编码基因 组成的共表达网络来预测不同可变加尾的非编码 RNA 的功能是本研究下一步的课题 ${ }^{[41 ~ 44]}$.

目前的研究中所使用的方法可能有一些新的挑 战. 例如, 本研究在整合构建的转录本和已知注释的 转录本时, 仅使用了 Cuffcompare. 为了能够更加精 确地检测 splice junction 及更加准确地构建转录本, 有人推荐在使用 TopHat 作回贴及 Cufflinks 构建转录 本时, 参照已有的基因注释. 而在本研究中, 在不参 照任何基因注释的情况下，重新构建了转录本. 同时, 在使用 Cuffcompare 进行转录本合并时，也没有依赖 已有的 Refseq, UCSC, Ensembl 及 GENCODE 的基因 
注释. 尽管如此, 还是利用 Cuffcompare 来除去不同 数据库中重复的转录本. 其除去重复转录本的原理 是, Cuffcompare 检查每个转录的结构, 任意 2 个转录 本只要具有相同的内含子结构, 就被认为是相同的 转录本, 那么相同的转录本的差别仅仅在第一个外 显子的前端和最后一个外显子的末端, 而对于来自 不同数据库注释的同一个转录本而言, 它们的区别 也是在第一个外显子的前端和最后一个外显子的末 端. 另外一个挑战是, 无法给出方法预测出的基因集
合的正确性和敏感性, 因为目前为止仍然缺乏衡量 它们正确性的精确集合. Yang 等人 ${ }^{[11]}$ 报道了不同细 胞系中不同形式的 mRNA 的比例构成也不同, 说明 不同条件下这些基因的转录本的形式会发生变化, 这同时也说明对于这些细胞系的研究, 要想精确地 判断所给基因集合的正确性和敏感性也是不现实的. 总体而言, 本研究虽然展示了一些基因的功能, 但是 对这 3 种可变加尾的基因在癌症或者其他疾病中所 发挥作用的研究还有很长的路要走.

\section{参考文献}

1 Wu Q, Kim Y C, Lu J, et al. Poly A-transcripts expressed in HeLa cells. PLoS ONE, 2008, 3: e2803

2 Cheng J, Kapranov P, Drenkow J, et al. Transcriptional maps of 10 human chromosomes at 5-nucleotide resolution. Science, 2005, 308: 1149-1154

3 Katinakis P, Slater A, Burdon R. Non-polyadenylated mRNAs from eukaryotes. FEBS Lett, 1980, 116: 1-7

4 Moore M J, Proudfoot N J. Pre-mRNA processing reaches back to transcription and ahead to translation. Cell, 2009, 136: 688-700

5 Grummt I. Regulation of mammalian ribosomal gene transcription by RNA polymerase I . Prog Nucleic Acid Re, 1998, 62: 109-154

6 Detke S, Stein J L, Stein G S. Synthesis of histone messenger RNAs by RNA polymerase II in nuclei from S phase HeLa S3 cells. Nucleic Acids Res, 1978, 5: 1515-1528

7 Willis I M. RNA Polymerase-Iii-genes, factors and transcriptional specificity. Eur J Biochem, 1993, 212: 1-11

8 Sunwoo H, Dinger M E, Wilusz J E, et al. MEN epsilon/beta nuclear-retained non-coding RNAs are up-regulated upon muscle differentiation and are essential components of paraspeckles. Genome Res, 2009, 19: 347-359

9 Wang E T, Sandberg R, Luo S, et al. Alternative isoform regulation in human tissue transcriptomes. Nature, 2008, 456: 470-476

10 Li J B, Levanon E Y, Yoon J K, et al. Genome-wide identification of human RNA editing sites by parallel DNA capturing and sequencing. Science, 2009, 324: 1210-1213

11 Yang L, Duff M O, Graveley B R, et al. Genomewide characterization of non-polyadenylated RNAs. Genome Biol, 2011, 12: R16

12 Cheng J, Kapranov P, Drenkow J, et al. Transcriptional maps of 10 human chromosomes at 5-nucleotide resolution. Science, 2005, 308: 1149-1154

13 Rosenbloom K R, Dreszer T R, Long J C, et al. ENCODE whole-genome data in the UCSC genome browser: update 2012. Nucleic Acids Res, 2012, 40: D912-D917

14 Trapnell C, Pachter L, Salzberg S L. TopHat: discovering splice junctions with RNA-seq. Bioinformatics, 2009, 25: 1105-1111

15 Langmead B, Trapnell C, Pop M, et al. Ultrafast and memory-efficient alignment of short DNA sequences to the human genome. Genome Biol, 2009, 10: R25

16 Trapnell C, Williams B A, Pertea G, et al. Transcript assembly and quantification by RNA-seq reveals unannotated transcripts and isoform switching during cell differentiation. Nat biotechnol, 2010, 28: 511-515

17 Garber M, Grabherr M G, Guttman M, et al. Computational methods for transcriptome annotation and quantification using RNA-seq. Nature Methods, 2011, 8: 469-477

18 Cabili M N, Trapnell C, Goff L, et al. Integrative annotation of human large intergenic noncoding RNAs reveals global properties and specific subclasses. Genes Devel, 2011, 25: 1915-1927

19 Hanahan D, Weinberg R A. Hallmarks of cancer: the next generation. Cell, 2011, 144: 646-674

20 Hoeijmakers J H J. DNA damage, aging, and cancer. New Engl J Med, 2009, 361: 1475-1485

21 Gong X, Wu R H, Wang H W, et al. Evaluating the consistency of differential expression of microRNA detected in human cancers. Mol Cancer Ther, 2011, 10: 752-760

22 Jackson S P, Bartek J. The DNA-damage response in human biology and disease. Nature, 2009, 461: 1071-1078

23 Massagué J. G1 cell-cycle control and cancer. Nature, 2004, 432: 298-306

24 Evan G I, Vousden K H. Proliferation, cell cycle and apoptosis in cancer. Nature, 2001, 411: 342-348

25 Wang L S, Xiong Y Y, Sun Y H, et al. HLungDB: an integrated database of human lung cancer research. Nucleic Acids Res, 2010, 38: 


\section{D665-D669}

26 Landi M T, Dracheva T, Rotunno M, et al. Gene expression signature of cigarette smoking and its role in lung adenocarcinoma development and survival. PLoS ONE, 2008, 3: e1651

27 Rohrbeck A, Neukirchen J, Rosskopf M, et al. Gene expression profiling for molecular distinction and characterization of laser captured primary lung cancers. J Transl Med, 2008, 6: 69

28 Wrage M, Ruosaari S, Eijk P P, et al. Genomic profiles associated with early micrometastasis in lung cancer: relevance of 4q deletion. Clin Cancer Res, 2009, 15: 1566-1574

29 Barnhart B C, Lam J C, Young R M, et al. Effects of 4E-BP1 expression on hypoxic cell cycle inhibition and tumor cell proliferation and survival. Cancer Biol Ther, 2008, 7: 1441-1449

30 She Q B, Halilovic E, Ye Q, et al. 4E-BP1 is a key effector of the oncogenic activation of the AKT and ERK signaling pathways that integrates their function in tumors. Cancer Cell, 2010, 18: 39-51

31 Collins K, Jacks T, Pavletich N P. Apoptosis: a review of programmed cell death. Toxicol Pathol, 2007, 35: 495-516

32 Zamai L, Ponti C, Mirandola P, et al. NK cells and cancer. J Immunol, 2007, 178: 4011-4016

33 Park M T, Lee S J. Cell cycle and cancer. J Biochem Mol Biol, 2003, 36: 60-65

34 Schadt E E, Linderman M D, Sorenson J, et al. Computational solutions to large-scale data management and analysis. Nat Rev Genet, 2010, 11: 647-657

35 Yang J, Yang F, Ren L, et al. Unbiased parallel detection of viral pathogens in clinical samples by use of a metagenomic approach. J Clin Microbiol, 2011, 49: 3463-3469

36 Sun L, Luo H T, Liao Q, et al. Systematic study of human long intergenic non-coding RNAs and their impact on cancer. Sci China Life Sci, 2013, 56, 324-334

37 Yu W, Gius D, Onyango P, et al. Epigenetic silencing of tumour suppressor gene p15 by its antisense RNA. Nature, 2008, 451: 202-206

38 Huarte M, Guttman M, Feldser D, et al. A large intergenic noncoding RNA induced by p53 mediates global gene repression in the p53 response. Cell, 2010, 142: 409-419

39 Esteller M. Non-coding RNAs in human disease. Nat Rev Genet, 2011, 12: 861-874

40 Prensner J R, Iyer M K, Balbin O A, et al. Transcriptome sequencing across a prostate cancer cohort identifies PCAT-1, an unannotated lincRNA implicated in disease progression. Nat Biotechnol, 2011, 29: 742-749

41 Liao Q, Xiao H, Bu D C, et al. NcFANs: a web server for functional annotation of long non-coding RNAs. Nucleic Acids Res, 2011, 39 : $\mathrm{W} 118-\mathrm{W} 124$

42 Liao Q, Liu C N, Yuan X Y, et al. Large-scale prediction of long non-coding RNA functions in a coding-non-coding gene co-expression network. Nucleic Acids Res, 2011, 39: 3864-3878

43 Bu D C, Yu K T, Sun S, et al. NONCODE v3.0: integrative annotation of long noncoding RNAs. Nucleic Acids Res, 2012, 40: D210-D215

44 Guo X L, Gao L, Liao Q, et al. Long non-coding RNAs function annotation: a global prediction method based on bi-colored networks. Nucleic Acids Res, 2013, 41: E35 


\section{论 文}

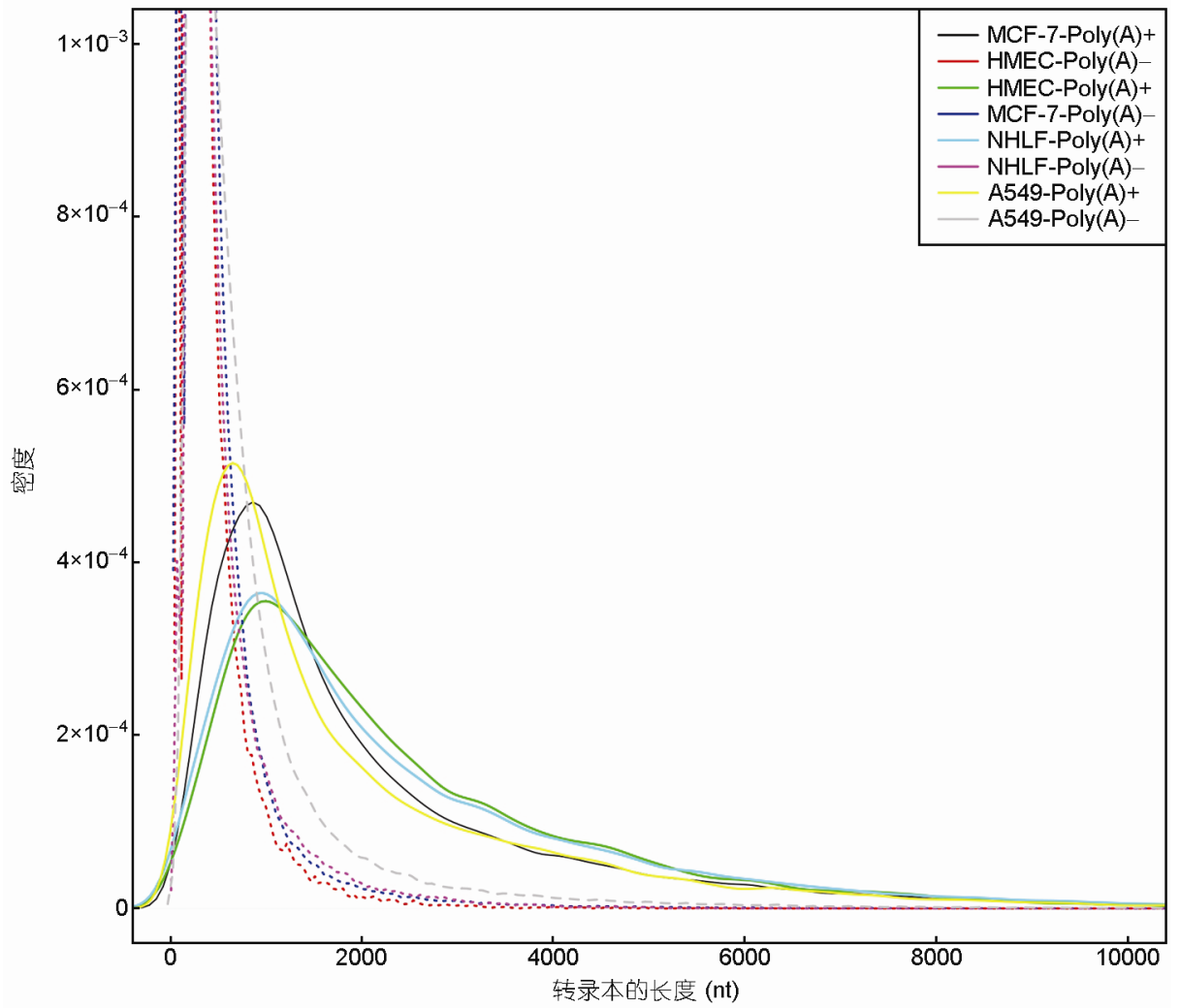

附图 1 从新构建的转录本的长度分布(来自 HMEC, MCF-7, NHLF 和 A549 这 4 个细胞系 8 个 RNA-seq 测序数据集)

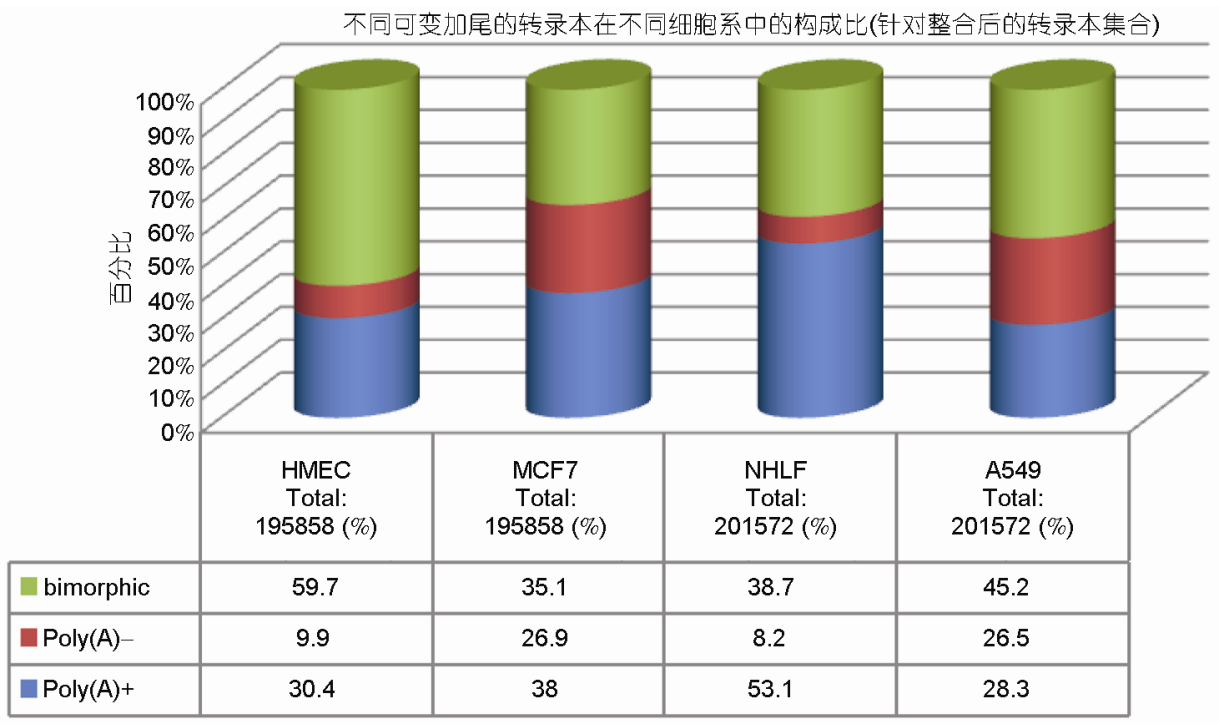

附图 2 从 HMEC, MCF-7, NHLF 和 A549 4 个细胞系中鉴定出来表达的 mRNA 

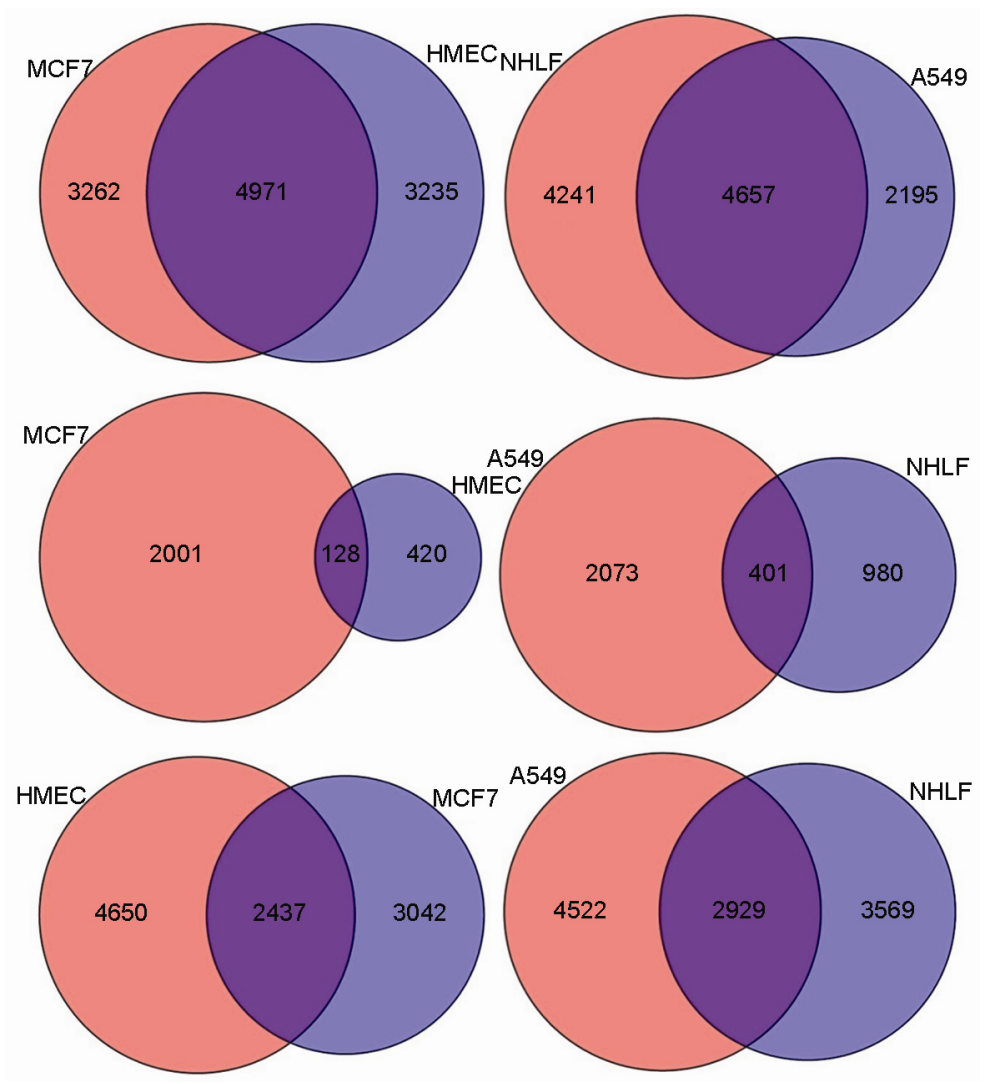

附图 3 正常和癌症对照的细胞系中鉴定出来的共同的蛋白编码基因的转录本, 第一行表示 poly(A)+ mRNA 之间的交集, 第二行表示 poly(A)- mRNA 之间的交集, 第三行表示 bimorphic mRNA 之间的交集, HMEC (人类乳腺上皮细胞系); MCF-7 (乳腺癌细胞系); NHLF(肺的正常成纤维细胞系);A549 (肺癌细胞系)

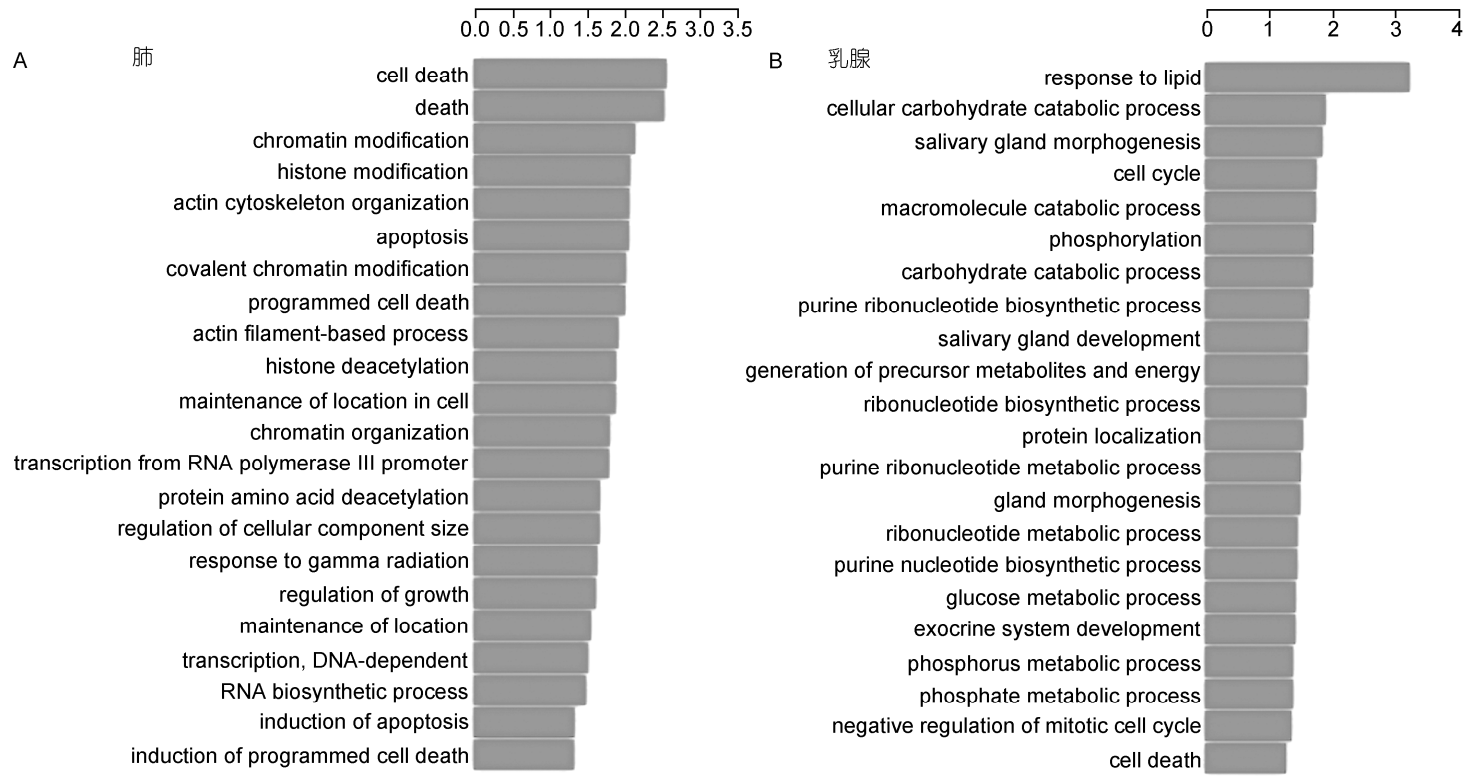

附图 4 癌症/正常表达下调的 poly(A)- mRNA 的 GO (gene ontology)功能富集情况 A: A549/NHLF; B: MCF7/HMEC 


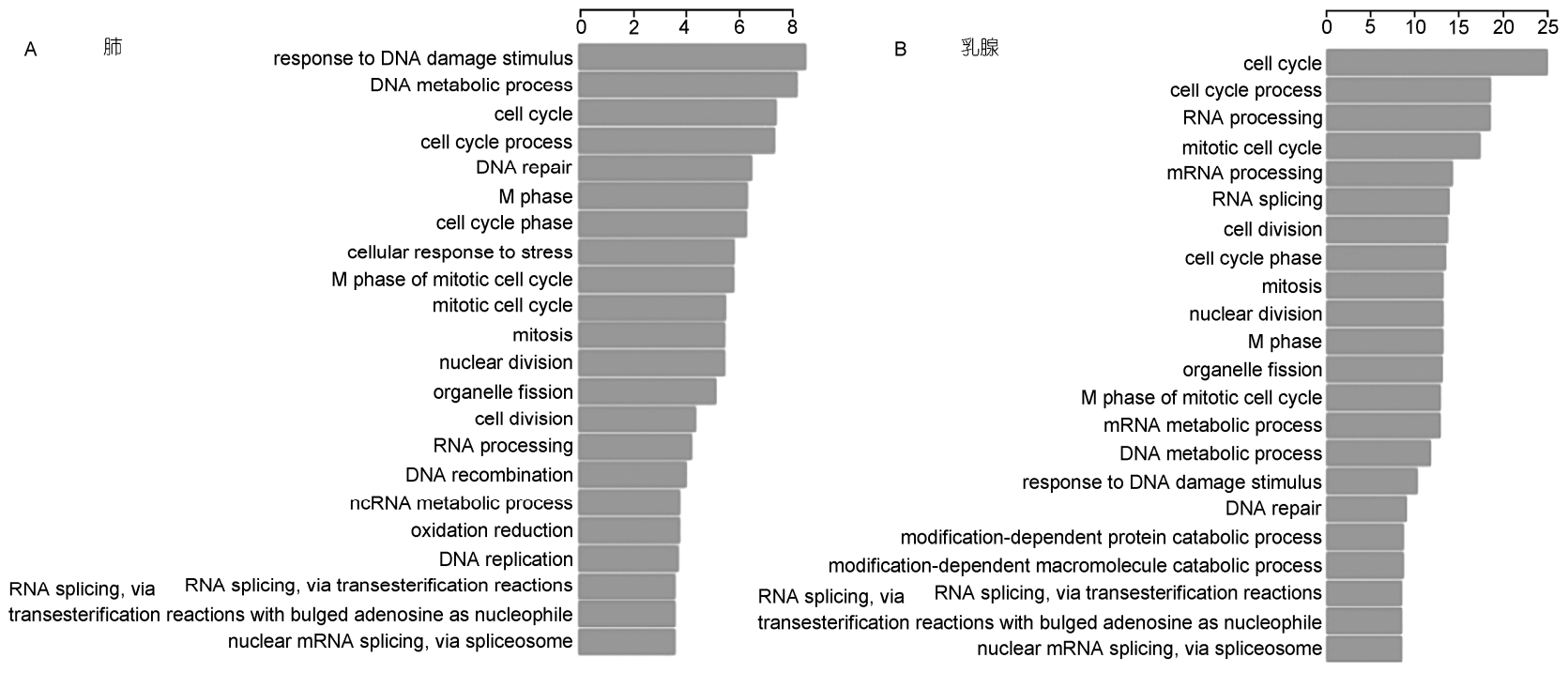

附图 5 癌症/正常表达上调的 poly(A)+ mRNA 的 GO (gene ontology)功能富集情况 A: A549/NHLF; B: MCF7/HMEC

A 肺

\begin{tabular}{r|r|r|r|r|r|r|r|} 
\\
intracellular transport & \\
vesicle-mediated transport & \\
cell death & \\
death & \\
protein localization & \\
sterol biosynthetic process & \\
romolecule catabolic process & \\
programmed cell death & \\
protein transport & \\
apoptosis & \\
\hline romolecule catabolic process & \\
\hline
\end{tabular}

establishment of protein localization induction of apoptosis induction of programmed cell death cellular macromolecule localization

positive regulation of apoptosis purine nucleotide metabolic process positive regulation of programmed cell death positive regulation of cell death

cellular protein localization

ribonucleotide metabolic process purine ribonucleotide metabolic process
B 乳腺

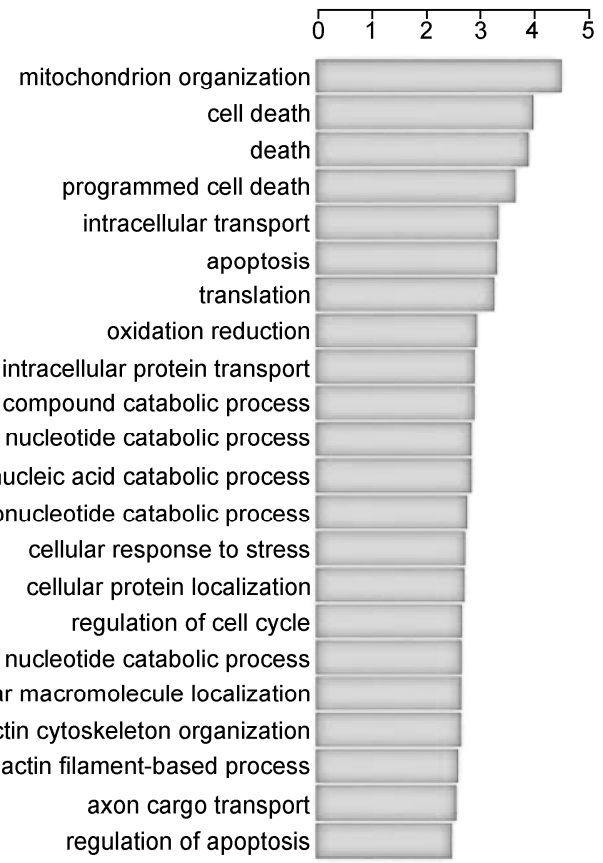

附图 6 癌症/正常表达下调的 poly(A)+ mRNA 的 GO (gene ontology)功能富集情况

A: A549/NHLF; B: MCF7/HMEC 


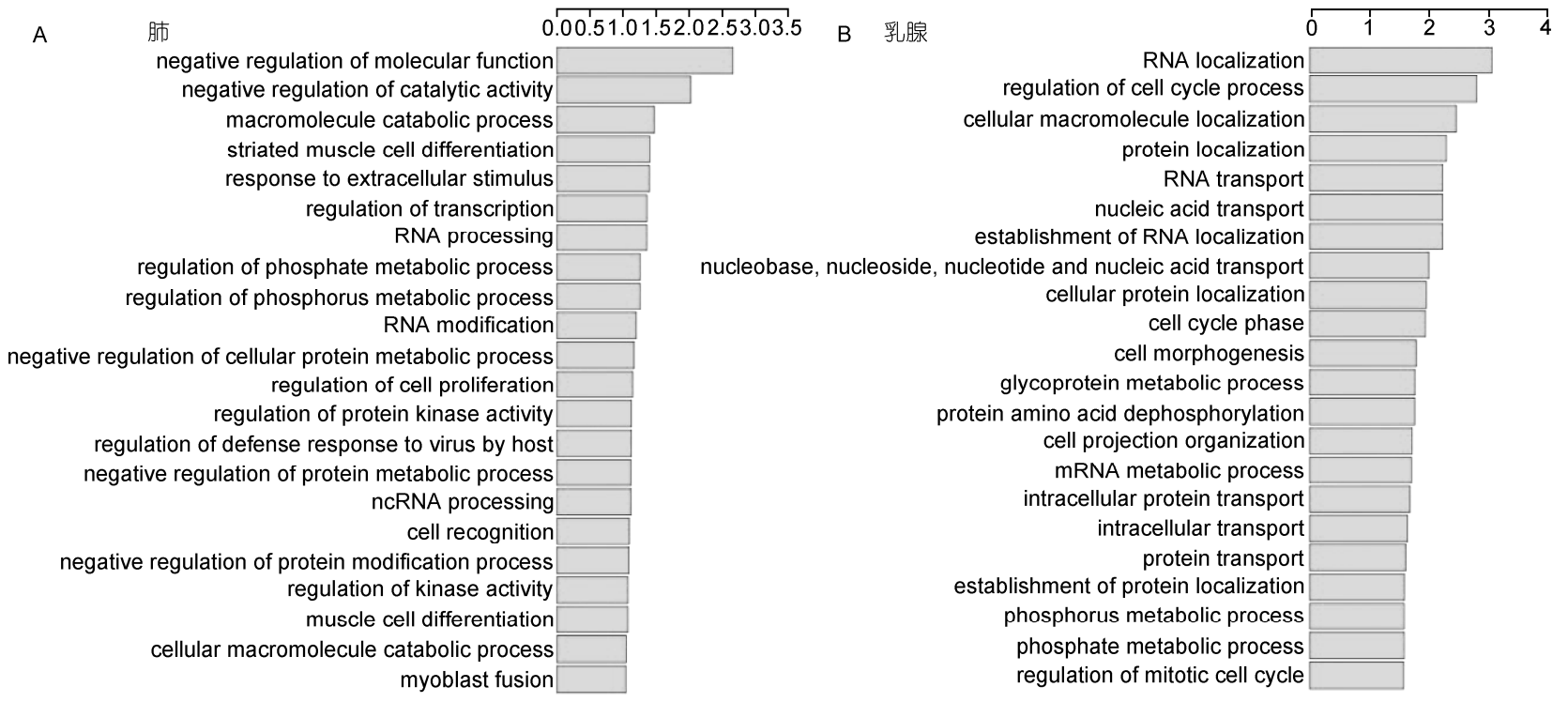

附图 7 在正常细胞系中表现为 poly(A)-, 在癌症细胞系中表现为 poly(A)+转换的 mRNA 的 GO (gene ontology) 功能富集情况

A: A549/NHLF; B: MCF7/HMEC; poly(A)-和 poly(A)+转换的 mRNA 是指同一个 mRNA, 在正常细胞系中被鉴定为 poly(A)- mRNA, 而在其 对应的癌症细胞系中被鉴定为 poly(A)+ mRNA, 或者反之

附表 1 人类不同细胞系的 RNA-seq 测序数据集(来自冷泉港实验室) ${ }^{\mathrm{a})}$

\begin{tabular}{cccccccc}
\hline 样本 & $\begin{array}{c}\text { 细胞系名称 } \\
\text { 缩写 }\end{array}$ & 位置描述 & $\begin{array}{c}\text { 细胞 } \\
\text { (正常/癌症) }\end{array}$ & RNA 类型 & 细胞系全称 & $\begin{array}{c}\text { 细胞系所在 } \\
\text { 位置 }\end{array}$ & $\begin{array}{c}\text { 细胞系 } \\
\text { 性别 }\end{array}$ \\
\hline GSM758571 & HMEC & 全细胞 & 正常 & long PolyA & $\begin{array}{c}\text { 正常人类乳腺上皮 } \\
\text { 细胞系 }\end{array}$ & 外胚层 & $\mathrm{U}^{*}$ \\
GSM765397 & HMEC & 全细胞 & 正常 & long non-polyA & $\begin{array}{c}\text { 正常人类乳腺上皮 } \\
\text { 细胞系 }\end{array}$ & 外胚层 & U \\
GSM765388 & MCF-7 & 全细胞 & 癌症 & long polyA & 人类乳腺癌细胞系 & 外胚层 & F \\
GSM767851 & MCF-7 & 全细胞 & 癌症 & long non-polyA & 人类乳腺癌细胞系 & 外胚层 & F \\
GSM765389 & NHLF & 全细胞 & 正常 & long non-polyA & 人类正常肺纤维母 & 内胚层 & U \\
GSM765394 & NHLF & 全细胞 & 正常 & long polyA & 人类正常肺纤维母 & 内胚层 & U \\
GSM758564 & A549 & 全细胞 & 癌症 & long polyA & 人类肺癌细胞系 & 内胚层 & M \\
GSM767854 & A549 & 全细胞 & 癌症 & long non-polyA & 人类肺癌细胞系 & 内胚层 & M \\
\hline
\end{tabular}

a) F：代表女性; M: 代表男性; U: 未知性别

附表 2 文章中所用到的数据集, 所有数据集基于 $\mathrm{Hg} 19$ 基因组

\begin{tabular}{cc}
\hline 数据库名称 & 转录本条数 \\
\hline Refseq & 41937 \\
UCSC 基因注释 & 77614 \\
GENCODE 长非编码 RNA 注释(版本 11) & 18566 \\
Ensembl 基因注释 & 168848 \\
pseudogene 假基因注释 & 18046 \\
\hline
\end{tabular}

